\title{
Assessment of Radioactive Materials and Heavy Metals in the Surface Soil around the Bayanwula Prospective Uranium Mining Area in China
}

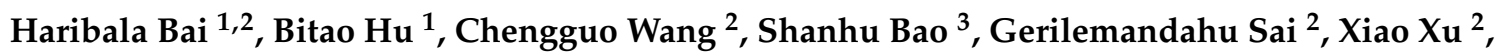 \\ Shuai Zhang ${ }^{2}$ and Yuhong $\mathrm{Li}^{1}{ }^{1}$ * \\ 1 School of Nuclear Science and Technology, Lanzhou University, Lanzhou 730000, China; \\ harbl12@lzu.edu.cn (H.B.); hubt@lzu.edu.cn (B.H.) \\ 2 The Inner Mongolia Autonomous Region Comprehensive Center for Disease Control and Prevention, \\ Huhhot 010031, China; wangcgcdc@163.com (C.W.); kaki2006119020@163.com (G.S.); \\ foxxiao1982@163.com (X.X.); zsacml@126.com (S.Z.) \\ 3 College of Geographical Science, Inner Mongolia Normal University, Huhhot 010022, China; \\ baoshanhu@imnu.edu.cn \\ * Correspondence: liyuhong@lzu.edu.cn
}

Academic Editor: Jason K. Levy

Received: 10 February 2017; Accepted: 9 March 2017; Published: 14 March 2017

\begin{abstract}
The present work is the first systematic and large scale study on radioactive materials and heavy metals in surface soil around the Bayanwula prospective uranium mining area in China. In this work, both natural and anthropogenic radionuclides and heavy metals in 48 surface soil samples were analyzed using High Purity Germanium (HPGe) $\gamma$ spectrometry and inductively coupled plasma-mass spectrometry (ICP-MS). The obtained mean activity concentrations of ${ }^{238} \mathrm{U}$, ${ }^{226} \mathrm{Ra},{ }^{232} \mathrm{Th},{ }^{40} \mathrm{~K}$, and ${ }^{137} \mathrm{Cs}$ were $25.81 \pm 9.58,24.85 \pm 2.77,29.40 \pm 3.14,923.0 \pm 47.2$, and $5.64 \pm 4.56 \mathrm{~Bq} / \mathrm{kg}$, respectively. The estimated average absorbed dose rate and annual effective dose rate were $76.7 \pm 3.1 \mathrm{nGy} / \mathrm{h}$ and $83.1 \pm 3.8 \mu \mathrm{Sv}$, respectively. The radium equivalent activity, external hazard index, and internal hazard index were also calculated, and their mean values were within the acceptable limits. The estimated lifetime cancer risk was $3.2 \times 10^{-4} / \mathrm{Sv}$. The heavy metal contents of $\mathrm{Cr}, \mathrm{Ni}, \mathrm{Cu}, \mathrm{Zn}, \mathrm{As}, \mathrm{Cd}$, and $\mathrm{Pb}$ from the surface soil samples were measured and their health risks were then assessed. The concentrations of all heavy metals were much lower than the average backgrounds in China except for lead which was about three times higher than that of China's mean. The non-cancer and cancer risks from the heavy metals were estimated, which are all within the acceptable ranges. In addition, the correlations between the radionuclides and the heavy metals in surface soil samples were determined by the Pearson linear coefficient. Strong positive correlations between radionuclides and the heavy metals at the 0.01 significance level were found. In conclusion, the contents of radionuclides and heavy metals in surface soil around the Bayanwula prospective uranium mining area are at a normal level.
\end{abstract}

Keywords: soil; radionuclide; heavy metal; uranium mining area; health risk

\section{Introduction}

Radiation exposure and heavy metal pollution around uranium mining areas have captured worldwide public attention for several decades [1-4]. The intensive uranium exploitation and the inappropriate management of the residues have had a harmful impact on the environment [4-6]. In recent decades, the dose contribution from technologically enhanced naturally occurring radioactive materials is increasing $[7,8]$. The worldwide annual effective dose to the public from natural radiation exposure is $2.4 \mathrm{mSv}$ [9], while it is $3.1 \mathrm{mSv}$ in China, which increased from $2.3 \mathrm{mSv}$ in 1990s [10-12]. 
The demand for uranium resources in China is increasing with the development of nuclear power industries $[9,13,14]$ and the rising price of uranium internationally [15]. Consequently, the activities on exploiting uranium ores and their hydrometallurgy processes were heavily strengthened and there are also some reports concerning the environmental contamination around uranium mines [16]. However, there have been few specific studies related to radionuclides and heavy metals assessment from uranium mining areas in China, especially around prospective uranium mining areas. A pre-mining study on radiation levels and heavy metals around uranium mining areas could establish a baseline database on the environmental radiation levels and become an essential reference guide for the future [17]. The aim of this study was to establish the radioactive materials and heavy metals contents from the surface soil around the Bayanwula uranium pre-mining area in China due to the lack of published environmental data, to assess the radiation and heavy metals risk for local residents, and to investigate the correlations between the radionuclides and heavy metals.

\section{Materials and Methods}

\subsection{Study Area}

The Bayanwula uranium mining region is located in the central part of the Sonid Left district, which is in the northwest part of the XilinGol prairie of Inner Mongolia in China. The study area is about $30 \mathrm{~km}$ north of the capital of Sonid Left. The altitude ranges from $1040 \mathrm{~m}$ to $1255 \mathrm{~m}$. There are around 34,000 residents in Sonid Left. This region has a continental climate with a warm summer and cold winter. The average annual precipitation is less than $200 \mathrm{~mm}$. The study area is characterized by grassland, not cultivated, and no industries. The sampling was carried out in June 2015 prior to the uranium mining activities. The map of the mining area and sampling locations are shown in Figure 1, in which the sampling locations were mapped using the software ESRI Arc GIS desktop 10.1 (Environmental Systems Research Institute, Inc., Redlands, CA, USA) based on the coordinates determined by the Global Positioning System (GPS).
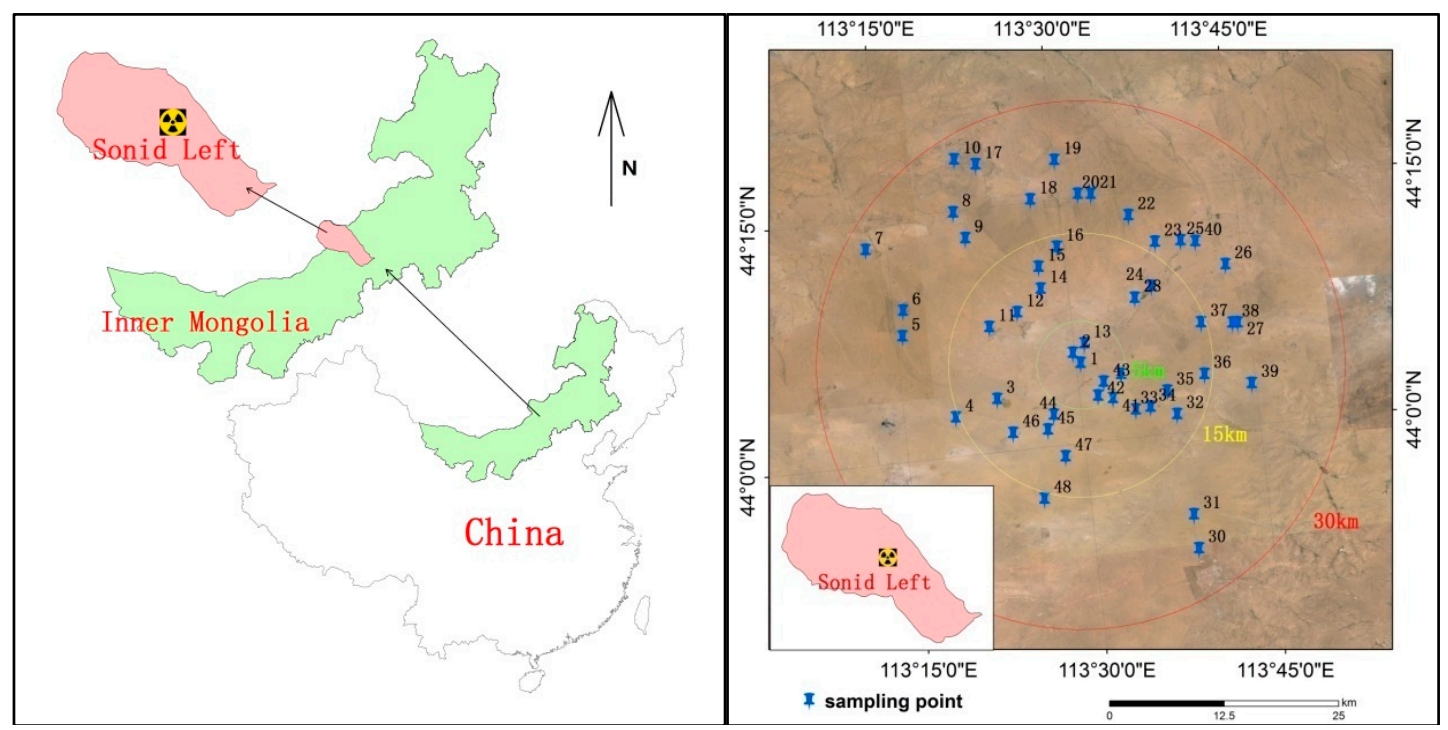

Figure 1. The map of the Bayanwula uranium mining area and sampling locations.

\subsection{Sampling and Preparation}

As shown in Figure 1, a total of 48 surface soil samples were collected within about a $30 \mathrm{~km}$ radius from the center of the mining area. At each sampling location, a square area of $1 \mathrm{~m}^{2}$ was marked out. Then four samples were collected from the surface layer (up to $10 \mathrm{~cm}$ ) of the four corners of the square area $(1 \mathrm{~m} \times 1 \mathrm{~m})$ using a stainless steel cylindrical sampler $(\varnothing 10 \mathrm{~cm} \times \mathrm{H} 10 \mathrm{~cm})$, mixed, and 
placed in a labeled polythene bag after removing impurities such as stones, gravels, and roots. In the laboratory, each sample was dried in an oven at $100{ }^{\circ} \mathrm{C}$ for more than $24 \mathrm{~h}$ to remove the moisture content, homogenized, and was separated into two parts. One of them was sieved through a $0.25 \mathrm{~mm}$ mesh. A sample of $338.0 \mathrm{~g}$ was weighed and sealed in an airtight polythene $(\varnothing 75 \mathrm{~cm} \times \mathrm{H70} \mathrm{cm})$ cylindrical container and left for more than 30 days to allow ${ }^{226} \mathrm{Ra}$ and its decay products to reach secular equilibrium before further gamma-ray measurement. The concentrations of ${ }^{238} \mathrm{U},{ }^{226} \mathrm{Ra},{ }^{232} \mathrm{Th}$, ${ }^{40} \mathrm{~K}$, and ${ }^{137} \mathrm{Cs}$ were determined by a HPGe $\gamma$-ray spectrometry system (Oak Ridge Technology \& Engineering Cooperation, Oak Ridge, TN, USA).

The other part was sieved through $0.150 \mathrm{~mm}$ mesh and weighed $0.2-0.5 \mathrm{~g}$ with accuracy up to $0.1 \mathrm{mg}$. They were then digested with a concentrated acid mixture $\left(\mathrm{HNO}_{3}, \mathrm{HF}\right.$, and $\left.\mathrm{HClO}_{4}\right)$ (Analytical reagent, EMD Millipore Corporation, Darmstadt, Germany). The solution was transferred to a 25 milliliter volumetric flask. The content of 7 elements $(\mathrm{Cr}, \mathrm{Ni}, \mathrm{Cu}, \mathrm{Zn}$, As (non-metal trace element), $\mathrm{Cd}$, and $\mathrm{Pb}$ ) was determined by inductively coupled plasma-mass spectrometry (ICP-MS) (Agilent Technologies Inc., Santa Clara, CA, USA). Lower limits of detection (LLDs) were determined as $10 \mu \mathrm{g} / \mathrm{kg}$ for $\mathrm{Cr}, 13 \mu \mathrm{g} / \mathrm{kg}$ for Ni, $13 \mu \mathrm{g} / \mathrm{kg}$ for $\mathrm{Cu}, 8 \mu \mathrm{g} / \mathrm{kg}$ for Zn, $3 \mu \mathrm{g} / \mathrm{kg}$ for As, $0.3 \mu \mathrm{g} / \mathrm{kg}$ for $\mathrm{Cd}$, and $7 \mu \mathrm{g} / \mathrm{kg}$ for $\mathrm{Pb}$ in dry soil weight.

HPGe $\gamma$-ray spectrometry system employed to carry out the radioactivity measurements was based on a high-purity germanium p-type coaxial photon detector made by Oak Ridge Technology \& Engineering Cooperation (ORTEC). The detector relative efficiency exceeded $32 \%$ while the resolution was better than $1.82 \mathrm{keV}$ at $1.33 \mathrm{MeV}{ }^{60} \mathrm{Co}$. The $\gamma$ spectrum of $40 \mathrm{keV}-3 \mathrm{MeV}$ was acquired and analyzed using the software Gamma vision (6.01) (Oak Ridge Technology \& Engineering Cooperation, Oak Ridge, TN, USA) and a 8192 multichannel analyzer (Oak Ridge Technology \& Engineering Cooperation, Oak Ridge, TN, USA). The whole detector system was placed inside a $10 \mathrm{~cm}$ lead layer shield. Before and after all sample counting, the backgrounds were measured and were subtracted from the corresponding photopeaks. The energy and efficiency calibrations of the counting system were performed using $\gamma$ sources of ${ }^{238} \mathrm{U},{ }^{234} \mathrm{Th},{ }^{226} \mathrm{Ra},{ }^{40} \mathrm{~K}$, and ${ }^{137} \mathrm{C}$ s with the same size of each sample. It took $86,400 \mathrm{~s}$ to reduce the counting statistical error for each measurement. The activity concentrations of ${ }^{238} \mathrm{U},{ }^{232} \mathrm{Th},{ }^{226} \mathrm{Ra},{ }^{40} \mathrm{~K},{ }^{137} \mathrm{Cs}$ in the soil samples were determined in $\mathrm{Bq} / \mathrm{kg}$ dry weight. The activity concentration of ${ }^{238} \mathrm{U}$ was derived from ${ }^{234} \mathrm{Th}(63.3 \mathrm{keV})$. The ${ }^{232} \mathrm{Th}$ in the soil samples was derived from ${ }^{212} \mathrm{~Pb}(238.6 \mathrm{keV}),{ }^{208} \mathrm{Tl}(538.2 \mathrm{keV})$, and ${ }^{228} \mathrm{Ac}(911.2 \mathrm{keV})$. The ${ }^{226} \mathrm{Ra}$ activity was determined by its daughter radionuclides ${ }^{214} \mathrm{~Pb}$ at $351.9 \mathrm{keV}$ and ${ }^{214} \mathrm{Bi}$ at $609.3 \mathrm{keV}$. The activity concentrations of ${ }^{40} \mathrm{~K}$ and ${ }^{137} \mathrm{C}$ s were derived from the photopeaks of 1460.8 and $661.7 \mathrm{keV}$, respectively. The minimum detectable activity for each radionuclide was determined from the HPGe $\gamma$-ray spectrometry system and samples for the counting time of $86,400 \mathrm{~s}$, and was estimated to be 3.7 Bq/ kg for ${ }^{238} \mathrm{U}, 0.1 \mathrm{~Bq} / \mathrm{kg}$ for ${ }^{232} \mathrm{Th}, 0.1 \mathrm{~Bq} / \mathrm{kg}$ for ${ }^{226} \mathrm{Ra}, 1.7 \mathrm{~Bq} / \mathrm{kg}$ for ${ }^{40} \mathrm{~K}$, and $0.01 \mathrm{~Bq} / \mathrm{kg}$ for ${ }^{137} \mathrm{Cs}$.

\subsection{Radiation Hazard Index Calculation}

The natural radioactivity of building materials is mainly from the ${ }^{238} \mathrm{U}$ series, ${ }^{232} \mathrm{Th}$ series, and ${ }^{40} \mathrm{~K}$. As $98.5 \%$ of the radiological effects of the uranium series are produced by radium and its daughter products, the contribution from ${ }^{238} \mathrm{U}$ has been replaced with the decay product ${ }^{226} \mathrm{Ra}[18,19]$. Therefore, the radiation hazard indices are usually determined by the activity concentrations of ${ }^{226} \mathrm{Ra},{ }^{232} \mathrm{Th}$, and ${ }^{40} \mathrm{~K}$.

\subsubsection{Absorbed $\gamma$ Dose Rate in Air}

The absorbed $\gamma$ dose rate $(\mathrm{nGy} / \mathrm{h})$ in air at $1 \mathrm{~m}$ above the ground for radionuclides $\left({ }^{238} \mathrm{U}\right.$ series, ${ }^{232} \mathrm{Th}$ series, and ${ }^{40} \mathrm{~K}$ ) uniformly distributed on the ground was computed by following Equation (1) [9].

$$
\mathrm{D}=0.462 \times \mathrm{A}_{\mathrm{Ra}}+0.604 \times \mathrm{A}_{\mathrm{Th}}+0.0417 \times \mathrm{A}_{\mathrm{K}}
$$


where $A_{R a}, A_{T h}$, and $A_{K}$ are the activity concentrations of ${ }^{226} \mathrm{Ra},{ }^{232} \mathrm{Th}$, and ${ }^{40} \mathrm{~K}(\mathrm{~Bq} / \mathrm{kg})$, respectively.

\subsubsection{Annual Effective Dose}

The annual effective dose is presented to express the irradiated dose of the human body from natural existing radionuclides in the earth's crust soil. It is expressed [9] by following Equation (2).

$$
\mathrm{AED}=\mathrm{D} \times 8760 \times 0.2(\text { or } 0.8) \times 0.7 \times 10^{-3}
$$

where AED is annual effective dose ( $\mu \mathrm{Sv} / \mathrm{y})$; $\mathrm{D}$ is $\gamma$ dose rate $(\mathrm{nGy} / \mathrm{h})$; the coefficient $0.7 \mathrm{~Sv} / \mathrm{Gy}$ is for the conversion coefficient from the absorbed dose in air to the effective dose received by adults; 0.2 for the outdoor occupancy factor; 8760 hour/year is equal to 365 days $\times 24$ h per year.

\subsubsection{Radium Equivalent Activity and External Hazard Index}

Both the radium equivalent activity $\left(\mathrm{Ra}_{\mathrm{eq}}\right)$ and the external hazard index $\left(\mathrm{H}_{\mathrm{ex}}\right)$ were equally used to evaluate the effect of the external $\gamma$ radiation on human beings. The radium equivalent activity and external hazard index were calculated by Equations (3) and (4). The $\mathrm{Ra}_{\mathrm{eq}}$ should not exceed $370 \mathrm{~Bq} / \mathrm{kg}$ and the $\mathrm{H}_{\mathrm{ex}}$ should be less than unity [10].

$$
\begin{aligned}
& \mathrm{Ra}_{\mathrm{eq}}=\mathrm{A}_{\mathrm{Ra}}+1.43 \times \mathrm{A}_{\mathrm{Th}}+0.077 \times \mathrm{A}_{\mathrm{K}} \\
& \mathrm{H}_{\mathrm{ex}}=\mathrm{A}_{\mathrm{Ra}} / 370+\mathrm{A}_{\mathrm{Th}} / 259+\mathrm{A}_{\mathrm{K}} / 4810
\end{aligned}
$$

\subsubsection{Internal Hazard Index}

The internal hazard index $\left(\mathrm{H}_{\text {in }}\right)$ was introduced to describe the hazard of radon and its short-lived products in building materials, given by Equation (5) and recommended to be less than unity [10].

$$
\mathrm{H}_{\mathrm{in}}=\mathrm{A}_{\mathrm{Ra}} / 185+\mathrm{A}_{\mathrm{Th}} / 259+\mathrm{A}_{\mathrm{K}} / 4810
$$

\subsubsection{Lifetime Cancer Risk}

The lifetime cancer risk (LTCR) was obtained by Equation (6) [11,12]:

$$
\mathrm{LTCR}=\mathrm{AED} \times \mathrm{DL} \times \mathrm{RFSE}
$$

where DL is the duration of lifetime, 70 years; and RFSE is the risk factor for stochastic effects of the common population, $0.055 / \mathrm{Sv}$ [12].

\subsection{Health Risk Assessment of Heavy Metals}

Human beings are exposed to soil metals through the ingestion and inhalation of dust particles through the mouth and nose, and dermal contact [20,21]. The health risk assessment model used in this study was developed by the US Environmental Protection Agency [22,23]. The doses are calculated as follows:

$$
\begin{gathered}
\mathrm{D}_{\text {ing }}=\frac{\mathrm{C} \times \mathrm{IngR} \times \mathrm{EF} \times \mathrm{ED}}{\mathrm{BW} \times \mathrm{AT}} \times 10^{-6} \\
\mathrm{D}_{\text {inh }}=\frac{\mathrm{C} \times \mathrm{InhR} \times \mathrm{EF} \times \mathrm{ED}}{\mathrm{PEF} \times \mathrm{BW} \times \mathrm{AT}} \\
\mathrm{D}_{\text {dermal }}=\frac{\mathrm{C} \times \mathrm{SA} \times \mathrm{SL} \times \mathrm{ABS} \times \mathrm{EF} \times \mathrm{ED}}{\mathrm{BW} \times \mathrm{AT}} \times 10^{-6}
\end{gathered}
$$

where $D_{\text {ing }}, D_{\text {inh }}, D_{\text {dermal }}$ are the average daily intake through ingestion, inhalation, and dermal absorption in $\mathrm{mg} /(\mathrm{kg}$.day), $\mathrm{C}$ is the concentration of metal in the soil $(\mathrm{mg} / \mathrm{kg}), \operatorname{IngR}$ and $\operatorname{InhR}$ are the ingestion and inhalation rate of soil, respectively $\left(\mathrm{mg} /\right.$ day, $\mathrm{m}^{3} /$ day), $\mathrm{EF}$ is the exposure frequency 
(day/year), and ED is the exposure duration (year). SA is the exposed skin area $\left(\mathrm{cm}^{2}\right)$, SL is the skin adherence factor, $\mathrm{ABS}$ is the dimensionless dermal absorption factor, PEF is the particle emission factor in $\mathrm{m}^{3} / \mathrm{kg}$, BW is the average body weight $(\mathrm{kg})$, and AT is the average time (day). The doses calculated for each element and exposure pathway are subsequently divided by the corresponding reference dose (RfD) (mg/(kg-day)) to yield a hazard quotient (HQ) (or non-cancer risk), whereas for carcinogens, the dose is multiplied by the corresponding slope factor $(\mathrm{SF})(\mathrm{mg} /(\mathrm{kg} \cdot \text { day }))^{-1}$ to produce a level of cancer risk. The hazard index (HI) is then the sum of $\mathrm{HQ}$ [24]. If $\mathrm{HI}<1$, it is believed that there is no significant risk of non-carcinogenic effects and the magnitude of risk increases as $\mathrm{HI}$ increases [23]. Carcinogenic risk is used to estimate the probability of an individual developing any type of cancer from the lifetime exposure to carcinogenic hazards. The acceptable risk for regulatory purposes is in the range of $10^{-6}-10^{-4}$ [20]. These values indicate that one additional case in a population of 1 million to one in 10,000 people is acceptable. In this study, hazard index methods and cancer risk methods were used to assess health risks of metal exposure to children and adults in the Bayanwula uranium pre-mining area. The detailed corresponding parameters are presented in Table $1[20,21,23,25]$.

Table 1. Parameters used to evaluate the exposure risk of soil metals.

\begin{tabular}{|c|c|c|c|}
\hline Parameter & Symbol & Unit & Value \\
\hline Soil ingestion rate & IngR & $\mathrm{mg} /$ day & 200 (child), 100 (adult) \\
\hline Exposure frequency & EF & day/year & 350 \\
\hline Soil inhalation rate & InhR & $\mathrm{m}^{3} /$ day & 7.6 (child), 20 (adult) \\
\hline Exposure duration & ED & year & 70 [6 (child) for non-cancer effects] \\
\hline Skin area & SA & $\mathrm{cm}^{2}$ & 860 (child), 1530 (adult) \\
\hline Skin adherence factor & SL & $\mathrm{mg} \cdot \mathrm{cm}^{2}$ & 0.2 (child), 0.07 (adult) \\
\hline Dermal absorption factor & ABS & unitless & $0.006(\mathrm{~Pb}), 0.14(\mathrm{Cd}), 0.1(\mathrm{Cu}), 0.02(\mathrm{Zn}), 0.05(\mathrm{Hg}), 0.03(\mathrm{As})$ \\
\hline Particle emission factor & PEF & $\mathrm{m}^{3} / \mathrm{kg}$ & $1.36 \times 10^{9}$ \\
\hline Body weight & BW & $\mathrm{kg}$ & 15 (child), 70 (adult) \\
\hline \multirow{2}{*}{ Averaging time } & \multirow{2}{*}{ AT } & \multirow{2}{*}{ day } & ED $\times 365$ days for non-carcinogens \\
\hline & & & $70 \times 365$ days for carcinogens \\
\hline Chronic reference dose & RfD & $\mathrm{mg} \cdot \mathrm{kg}^{-1} \cdot \mathrm{day}^{-1}$ & $\begin{array}{c}\text { Ingestion RfD: } 3.00 \times 10^{-3}(\mathrm{Cr}), 2.00 \times 10^{-2}(\mathrm{Ni}) \\
4.00 \times 10^{-2}(\mathrm{Cu}), 3.00 \times 10^{-1}(\mathrm{Zn}), 3.00 \times 10^{-4}(\mathrm{As}) \\
1.00 \times 10^{-3}(\mathrm{Cd}), 3.50 \times 10^{-3}(\mathrm{~Pb})\end{array}$ \\
\hline \multirow{5}{*}{ Carcinogenic slope factor } & \multirow{5}{*}{ SF } & \multirow{5}{*}{$\left(\mathrm{mg} \cdot \mathrm{kg}^{-1} \cdot \mathrm{day}^{-1}\right)^{-1}$} & $\begin{array}{l}\text { Inhalation RfD: } 2.86 \times 10^{-5}(\mathrm{Cr}), 2.06 \times 10^{-2}(\mathrm{Ni}) \\
\qquad \begin{array}{c}4.02 \times 10^{-2}(\mathrm{Cu}), 3.00 \times 10^{-1}(\mathrm{Zn}) \\
3.01 \times 10^{-4}(\mathrm{As}), 3.25 \times 10^{-3}(\mathrm{~Pb})\end{array}\end{array}$ \\
\hline & & & $\begin{array}{c}\text { Dermal RfD: } 6.00 \times 10^{-5}(\mathrm{Cr}), 5.40 \times 10^{-5}(\mathrm{Ni}) \\
1.20 \times 10^{-2}(\mathrm{Cu}), 6.00 \times 10^{-6}(\mathrm{Zn}), 1.23 \times 10^{-4}(\mathrm{As}) \\
1.00 \times 10^{-5}(\mathrm{Cd}), 5.25 \times 10^{-4}(\mathrm{~Pb})\end{array}$ \\
\hline & & & Ingestion SF: $1.5(\mathrm{As})$ \\
\hline & & & $\begin{array}{c}\text { Inhalation SF: } 4.20 \times 10^{1}(\mathrm{Cr}), 8.40 \times 10^{-1}(\mathrm{Ni}) \\
1.51 \times 10^{1}(\mathrm{As}), 6.30(\mathrm{Cd})\end{array}$ \\
\hline & & & Dermal SF: 3.66 (As) \\
\hline
\end{tabular}

\section{Results and Discussion}

\subsection{Radionuclides}

The activity concentrations of radionuclides $\left({ }^{238} \mathrm{U},{ }^{232} \mathrm{Th},{ }^{226} \mathrm{Ra},{ }^{40} \mathrm{~K}\right.$, and $\left.{ }^{137} \mathrm{Cs}\right)$ in 48 surface soil samples around the Bayanwula prospective uranium mining area are presented in Table 2 . The mean values of ${ }^{238} \mathrm{U},{ }^{232} \mathrm{Th}$, and ${ }^{226} \mathrm{Ra}$ are lower than the China and world mean values. However, the mean value of ${ }^{40} \mathrm{~K}$ was around two times higher than both the worldwide and China's average of 412 [6] and $580.0 \mathrm{~Bq} / \mathrm{kg}$ [26], respectively. The activity concentration of ${ }^{137} \mathrm{Cs}$ was $5.64 \mathrm{~Bq} / \mathrm{kg}$, which was the anthropogenic radionuclide from nuclear weapon tests or nuclear power accidents. The absorbed $\gamma$ dose rate in air, annual effective dose, hazard indices, and lifetime cancer risk calculated from radionuclides in soil samples are shown in Table 3. The calculated mean outdoor $\gamma$ dose rates 
was $76.7 \mathrm{nGy} \cdot \mathrm{h}^{-1}$, which was higher than the world average of $60 \mathrm{nGy} / \mathrm{h}[6]$ and the Chinese mean value of $62.8 \mathrm{nGy} / \mathrm{h} \mathrm{[26]}$. The mean value of radium equivalent activity was $138.0 \mathrm{~Bq} / \mathrm{kg}$, lower than the reference value of $370 \mathrm{~Bq} / \mathrm{kg}$. The external and internal hazard indices did not exceed unity, which indicates that the $\gamma$ radiation from the soil was at a safe level. The lifetime cancer risk was $3.2 \times 10^{-4} / \mathrm{Sv}$, which was also at a very low level.

\subsection{Heavy Metals}

The contents of heavy metals $(\mathrm{Cr}, \mathrm{Ni}, \mathrm{Cu}, \mathrm{Zn}, \mathrm{As}, \mathrm{Cd}$, and $\mathrm{Pb})$ in surface soil from the prospective uranium mining area, background values of Inner Mongolia, mean values of China [27,28], and China soil guidelines [29] are also given in Table 2. The mean concentrations of $\mathrm{Cr}, \mathrm{Ni}, \mathrm{Cu}, \mathrm{Zn}, \mathrm{As}$, and $\mathrm{Cd}$ are much lower than both the national mean backgrounds and the grade I soil quality standard (This level is mainly applicable to the national nature reserve except for the high background areas). However, the concentration of $\mathrm{Pb}$ is much higher than China's background value and within the grade II soil quality standard (The level is mainly applied to general farmland, vegetable land, tea garden, orchard, pasture, and other soil; the soil quality basically could not cause harm and pollution to plants and the environment). The results of the health risk assessment of the heavy metals in the soil around the study area are listed in Table 4 for children and Table 5 for adults. For non-cancer risk, the ingestion dose of the heavy metals is significant for children and adults. The non-cancer risk of the heavy metals for children is higher than that for adults. The hazard indices (HIs) decrease in the order of $\mathrm{Pb}>\mathrm{Cr}>$ As $>\mathrm{Ni}>\mathrm{Cu}>\mathrm{Cd}>\mathrm{Zn}$ for both children and adults are all lower than unity. For cancer risk, $\mathrm{Cr}, \mathrm{Ni}$, As and $\mathrm{Cd}$ were considered in this study. The cancer risk from the heavy metals is much lower than the acceptable range of $10^{-4}$. It can be clearly seen from the tables that the non-cancer risk is more important than the cancer risk for both children and adults. These results indicate that both the cancer and non-cancer risks for the children and adults living around the Bayanwula prospective uranium mining region are all at acceptable levels. 
Table 2. The contents of radionuclides $(\mathrm{Bq} / \mathrm{kg})$ and heavy metals $(\mathrm{mg} / \mathrm{kg})$ in surface soil samples around the Bayanwula prospective uranium mining area.

\begin{tabular}{|c|c|c|c|c|c|c|c|c|c|c|c|c|}
\hline No. & ${ }^{238} \mathrm{U}$ & ${ }^{232} \mathrm{Th}$ & ${ }^{226} \mathrm{Ra}$ & ${ }^{40} \mathrm{~K}$ & ${ }^{137} \mathrm{Cs}$ & $\mathrm{Cr}$ & $\mathbf{N i}$ & $\mathrm{Cu}$ & $\mathrm{Zn}$ & As & $\mathrm{Cd}$ & $\mathbf{P b}$ \\
\hline 1 & $20 \pm 2^{a}$ & $30 \pm 3$ & $26 \pm 3$ & $887 \pm 80$ & $9.6 \pm 1.0$ & $12.6 \pm 0.1^{b}$ & $5.4 \pm 0.1$ & $4.8 \pm 0.0$ & $16.7 \pm 0.2$ & $0.9 \pm 0.0$ & $0.010 \pm 0.004$ & $76.5 \pm 1.1$ \\
\hline 2 & $16 \pm 2$ & $28 \pm 3$ & $24 \pm 2$ & $885 \pm 80$ & $2.2 \pm 0.2$ & $13.4 \pm 0.2$ & $5.3 \pm 0.0$ & $4.7 \pm 0.0$ & $15.0 \pm 0.4$ & $0.9 \pm 0.0$ & $0.006 \pm 0.002$ & $73.4 \pm 0.9$ \\
\hline 3 & $25 \pm 2$ & $28 \pm 3$ & $24 \pm 2$ & $942 \pm 85$ & $4.9 \pm 0.5$ & $12.3 \pm 0.2$ & $5.3 \pm 0.0$ & $4.9 \pm 0.0$ & $15.9 \pm 0.1$ & $1.1 \pm 0.0$ & $0.006 \pm 0.001$ & $72.5 \pm 0.5$ \\
\hline 4 & $21 \pm 2$ & $28 \pm 3$ & $24 \pm 2$ & $927 \pm 83$ & $3.0 \pm 0.3$ & $11.0 \pm 0.2$ & $4.8 \pm 0.0$ & $4.4 \pm 0.1$ & $15.0 \pm 0.1$ & $1.1 \pm 0.0$ & $0.002 \pm 0.002$ & $41.6 \pm 0.7$ \\
\hline 5 & $44 \pm 4$ & $27 \pm 3$ & $23 \pm 2$ & $969 \pm 87$ & $13.9 \pm 1.4$ & $12.8 \pm 0.0$ & $5.6 \pm 0.0$ & $5.0 \pm 0.1$ & $17.2 \pm 0.2$ & $1.2 \pm 0.0$ & $0.006 \pm 0.002$ & $67.2 \pm 0.3$ \\
\hline 6 & $23 \pm 2$ & $30 \pm 3$ & $26 \pm 2$ & $933 \pm 84$ & $5.1 \pm 0.5$ & $14.3 \pm 0.5$ & $5.8 \pm 0.1$ & $5.5 \pm 0.1$ & $17.3 \pm 0.3$ & $1.2 \pm 0.0$ & $0.004 \pm 0.001$ & $68.3 \pm 1.1$ \\
\hline 7 & $22 \pm 2$ & $28 \pm 3$ & $25 \pm 2$ & $969 \pm 87$ & $6.2 \pm 0.6$ & $17.4 \pm 0.1$ & $5.1 \pm 0.0$ & $4.8 \pm 0.0$ & $19.2 \pm 0.1$ & $1.0 \pm 0.0$ & $0.005 \pm 0.003$ & $93.8 \pm 0.6$ \\
\hline 8 & $34 \pm 3$ & $32 \pm 3$ & $26 \pm 2$ & $964 \pm 87$ & $2.2 \pm 0.2$ & $16.6 \pm 0.2$ & $6.0 \pm 0.0$ & $5.8 \pm 0.0$ & $20.0 \pm 0.2$ & $1.1 \pm 0.0$ & $0.005 \pm 0.001$ & $96.0 \pm 0.3$ \\
\hline 9 & $23 \pm 2$ & $30 \pm 3$ & $26 \pm 3$ & $984 \pm 89$ & $8.4 \pm 0.8$ & $16.4 \pm 0.2$ & $4.8 \pm 0.1$ & $4.4 \pm 0.1$ & $17.4 \pm 0.4$ & $0.9 \pm 0.0$ & $0.003 \pm 0.001$ & $73.5 \pm 3.7$ \\
\hline 10 & $22 \pm 2$ & $35 \pm 3$ & $29 \pm 3$ & $929 \pm 84$ & $6.2 \pm 0.6$ & $17.3 \pm 0.2$ & $5.3 \pm 0.1$ & $4.9 \pm 0.1$ & $18.2 \pm 0.3$ & $1.2 \pm 0.0$ & $0.007 \pm 0.004$ & $88.2 \pm 1.5$ \\
\hline 11 & $29 \pm 3$ & $20 \pm 2$ & $17 \pm 2$ & $977 \pm 88$ & $10.0 \pm 1.0$ & $15.4 \pm 0.2$ & $4.6 \pm 0.0$ & $4.3 \pm 0.0$ & $16.3 \pm 0.1$ & $1.1 \pm 0.0$ & $0.016 \pm 0.001$ & $73.0 \pm 0.2$ \\
\hline 12 & $14 \pm 1$ & $28 \pm 3$ & $22 \pm 2$ & $875 \pm 79$ & $8.8 \pm 0.9$ & $14.4 \pm 0.1$ & $6.0 \pm 0.1$ & $5.5 \pm 0.1$ & $16.3 \pm 0.2$ & $1.0 \pm 0.0$ & $0.012 \pm 0.006$ & $69.7 \pm 1.9$ \\
\hline 13 & $25 \pm 2$ & $31 \pm 3$ & $29 \pm 3$ & $852 \pm 77$ & $6.3 \pm 0.6$ & $13.7 \pm 0.1$ & $5.9 \pm 0.0$ & $5.5 \pm 0.0$ & $16.6 \pm 0.1$ & $1.0 \pm 0.0$ & $0.010 \pm 0.003$ & $67.1 \pm 0.2$ \\
\hline 14 & $18 \pm 2$ & $29 \pm 3$ & $24 \pm 2$ & $937 \pm 84$ & $15.5 \pm 1.6$ & $16.9 \pm 0.5$ & $4.6 \pm 0.1$ & $4.6 \pm 0.2$ & $18.8 \pm 0.8$ & $0.9 \pm 0.0$ & $0.009 \pm 0.003$ & $70.3 \pm 5.2$ \\
\hline 15 & $13 \pm 1$ & $29 \pm 3$ & $26 \pm 2$ & $984 \pm 89$ & $4.9 \pm 0.5$ & $17.5 \pm 0.1$ & $5.1 \pm 0.1$ & $4.6 \pm 0.0$ & $17.5 \pm 0.2$ & $1.1 \pm 0.0$ & $0.004 \pm 0.003$ & $70.1 \pm 1.7$ \\
\hline 16 & $24 \pm 2$ & $32 \pm 3$ & $26 \pm 3$ & $967 \pm 87$ & $1.4 \pm 0.1$ & $17.6 \pm 0.1$ & $6.0 \pm 0.1$ & $5.4 \pm 0.1$ & $18.3 \pm 0.3$ & $1.2 \pm 0.0$ & $0.001 \pm 0.001$ & $71.1 \pm 0.6$ \\
\hline 17 & $37 \pm 4$ & $36 \pm 3$ & $32 \pm 3$ & $866 \pm 78$ & $1.5 \pm 0.2$ & $15.4 \pm 0.4$ & $8.7 \pm 0.1$ & $7.9 \pm 0.1$ & $23.2 \pm 0.3$ & $1.1 \pm 0.0$ & $0.009 \pm 0.004$ & $81.1 \pm 0.5$ \\
\hline 18 & $58 \pm 6$ & $33 \pm 3$ & $27 \pm 3$ & $919 \pm 83$ & $3.2 \pm 0.3$ & $12.9 \pm 0.2$ & $6.3 \pm 0.0$ & $6.2 \pm 0.1$ & $19.9 \pm 0.5$ & $1.3 \pm 0.0$ & $0.009 \pm 0.001$ & $72.5 \pm 0.3$ \\
\hline 19 & $17 \pm 2$ & $30 \pm 3$ & $23 \pm 2$ & $807 \pm 73$ & $4.2 \pm 0.4$ & $12.2 \pm 0.4$ & $6.8 \pm 0.1$ & $6.8 \pm 0.1$ & $19.8 \pm 0.3$ & $1.2 \pm 0.0$ & $0.020 \pm 0.004$ & $70.6 \pm 1.7$ \\
\hline 20 & $30 \pm 3$ & $28 \pm 3$ & $24 \pm 2$ & $934 \pm 84$ & $15.6 \pm 1.6$ & $15.0 \pm 0.1$ & $5.8 \pm 0.1$ & $5.5 \pm 0.1$ & $19.8 \pm 0.0$ & $1.2 \pm 0.0$ & $0.011 \pm 0.001$ & $78.0 \pm 0.7$ \\
\hline 21 & $24 \pm 2$ & $32 \pm 3$ & $27 \pm 3$ & $929 \pm 84$ & $0.6 \pm 0.1$ & $16.2 \pm 0.3$ & $5.9 \pm 0.1$ & $5.9 \pm 0.1$ & $19.3 \pm 0.5$ & $1.3 \pm 0.1$ & $0.004 \pm 0.003$ & $65.0 \pm 0.6$ \\
\hline 22 & $27 \pm 3$ & $31 \pm 3$ & $26 \pm 3$ & $957 \pm 86$ & $4.1 \pm 0.4$ & $14.6 \pm 0.1$ & $5.7 \pm 0.1$ & $5.4 \pm 0.1$ & $18.4 \pm 0.3$ & $1.2 \pm 0.0$ & $0.006 \pm 0.004$ & $75.1 \pm 0.4$ \\
\hline 23 & $31 \pm 3$ & $30 \pm 3$ & $27 \pm 3$ & $955 \pm 86$ & $14.6 \pm 1.5$ & $16.9 \pm 0.2$ & $5.1 \pm 0.1$ & $4.9 \pm 0.1$ & $18.0 \pm 0.3$ & $1.0 \pm 0.0$ & $0.005 \pm 0.004$ & $78.6 \pm 0.3$ \\
\hline 24 & $31 \pm 3$ & $28 \pm 3$ & $24 \pm 2$ & $850 \pm 77$ & $1.9 \pm 0.2$ & $13.2 \pm 0.2$ & $6.3 \pm 0.1$ & $6.2 \pm 0.1$ & $17.8 \pm 0.4$ & $1.5 \pm 0.0$ & $0.016 \pm 0.001$ & $65.9 \pm 0.4$ \\
\hline 25 & $38 \pm 4$ & $31 \pm 3$ & $25 \pm 2$ & $928 \pm 84$ & $2.8 \pm 0.3$ & $15.0 \pm 0.1$ & $7.5 \pm 0.1$ & $7.7 \pm 0.1$ & $22.0 \pm 0.1$ & $1.4 \pm 0.0$ & $0.019 \pm 0.001$ & $77.2 \pm 1.5$ \\
\hline 26 & $11 \pm 1$ & $24 \pm 2$ & $19 \pm 2$ & $901 \pm 81$ & $15.0 \pm 1.5$ & $13.2 \pm 0.3$ & $6.2 \pm 0.0$ & $5.9 \pm 0.0$ & $18.4 \pm 0.5$ & $1.1 \pm 0.0$ & $0.017 \pm 0.008$ & $75.2 \pm 1.8$ \\
\hline 27 & $27 \pm 3$ & $32 \pm 3$ & $27 \pm 3$ & $945 \pm 85$ & $2.6 \pm 0.3$ & $16.7 \pm 0.3$ & $6.3 \pm 0.1$ & $5.8 \pm 0.1$ & $18.4 \pm 0.6$ & $1.2 \pm 0.0$ & $0.005 \pm 0.002$ & $69.3 \pm 1.8$ \\
\hline 28 & $23 \pm 2$ & $33 \pm 3$ & $28 \pm 3$ & $885 \pm 80$ & $2.0 \pm 0.2$ & $14.6 \pm 0.2$ & $7.1 \pm 0.0$ & $6.8 \pm 0.1$ & $18.1 \pm 0.4$ & $1.1 \pm 0.0$ & $0.009 \pm 0.004$ & $69.3 \pm 0.3$ \\
\hline 29 & $7 \pm 1$ & $26 \pm 2$ & $22 \pm 2$ & $947 \pm 85$ & $1.8 \pm 0.2$ & $13.8 \pm 0.2$ & $5.6 \pm 0.0$ & $5.2 \pm 0.1$ & $15.3 \pm 0.2$ & $1.1 \pm 0.0$ & $0.000 \pm 0.000$ & $71.4 \pm 0.6$ \\
\hline 30 & $40 \pm 4$ & $31 \pm 3$ & $25 \pm 2$ & $958 \pm 86$ & $0.2 \pm 0.0$ & $14.7 \pm 0.1$ & $6.3 \pm 0.0$ & $5.9 \pm 0.0$ & $17.1 \pm 0.1$ & $1.0 \pm 0.0$ & $0.008 \pm 0.000$ & $71.9 \pm 0.1$ \\
\hline 31 & $34 \pm 3$ & $32 \pm 3$ & $26 \pm 2$ & $908 \pm 82$ & $2.7 \pm 0.3$ & $15.9 \pm 0.2$ & $6.8 \pm 0.1$ & $6.0 \pm 0.1$ & $18.9 \pm 0.4$ & $1.2 \pm 0.0$ & $0.007 \pm 0.002$ & $68.2 \pm 0.1$ \\
\hline 32 & $23 \pm 2$ & $27 \pm 3$ & $26 \pm 2$ & $969 \pm 87$ & $6.7 \pm 0.7$ & $14.8 \pm 0.3$ & $6.7 \pm 0.0$ & $6.2 \pm 0.1$ & $19.2 \pm 0.2$ & $1.2 \pm 0.0$ & $0.013 \pm 0.003$ & $71.5 \pm 1.1$ \\
\hline 33 & $33 \pm 3$ & $28 \pm 3$ & $23 \pm 2$ & $927 \pm 83$ & $6.1 \pm 0.6$ & $13.7 \pm 0.1$ & $6.4 \pm 0.1$ & $6.0 \pm 0.1$ & $18.2 \pm 0.3$ & $1.2 \pm 0.0$ & $0.016 \pm 0.003$ & $73.0 \pm 0.3$ \\
\hline 34 & $12 \pm 1$ & $27 \pm 3$ & $23 \pm 2$ & $936 \pm 84$ & $3.4 \pm 0.3$ & $14.8 \pm 0.3$ & $6.9 \pm 0.1$ & $6.4 \pm 0.1$ & $19.0 \pm 0.2$ & $1.3 \pm 0.0$ & $0.004 \pm 0.002$ & $71.7 \pm 0.4$ \\
\hline 35 & $34 \pm 3$ & $35 \pm 3$ & $27 \pm 3$ & $907 \pm 82$ & $2.1 \pm 0.2$ & $17.5 \pm 0.1$ & $9.6 \pm 0.1$ & $9.0 \pm 0.1$ & $23.3 \pm 0.5$ & $1.4 \pm 0.0$ & $0.015 \pm 0.003$ & $75.3 \pm 0.5$ \\
\hline 36 & $15 \pm 2$ & $35 \pm 3$ & $30 \pm 3$ & $777 \pm 70$ & $5.3 \pm 0.5$ & $18.5 \pm 0.3$ & $10.4 \pm 0.1$ & $8.9 \pm 0.1$ & $25.3 \pm 0.3$ & $1.4 \pm 0.0$ & $0.023 \pm 0.007$ & $77.7 \pm 1.8$ \\
\hline
\end{tabular}


Table 2. Cont.

\begin{tabular}{|c|c|c|c|c|c|c|c|c|c|c|c|c|}
\hline No. & ${ }^{238} \mathrm{U}$ & ${ }^{232} \mathrm{Th}$ & ${ }^{226} \mathrm{Ra}$ & ${ }^{40} \mathrm{~K}$ & ${ }^{137} \mathrm{Cs}$ & $\mathrm{Cr}$ & $\mathbf{N i}$ & $\mathrm{Cu}$ & Zn & As & Cd & $\mathrm{Pb}$ \\
\hline 37 & $33 \pm 3$ & $26 \pm 2$ & $22 \pm 2$ & $880 \pm 97$ & $13.1 \pm 1.3$ & $16.0 \pm 0.3$ & $6.6 \pm 0.1$ & $5.9 \pm 0.1$ & $21.5 \pm 0.4$ & $1.0 \pm 0.0$ & $0.025 \pm 0.007$ & $75.5 \pm 0.2$ \\
\hline 38 & $34 \pm 3$ & $35 \pm 3$ & $29 \pm 3$ & $867 \pm 78$ & $4.8 \pm 0.5$ & $15.4 \pm 0.2$ & $6.9 \pm 0.1$ & $6.3 \pm 0.1$ & $19.3 \pm 0.4$ & $1.2 \pm 0.0$ & $0.009 \pm 0.002$ & $73.7 \pm 1.7$ \\
\hline 39 & $35 \pm 4$ & $32 \pm 3$ & $28 \pm 3$ & $858 \pm 77$ & $10.7 \pm 1.1$ & $14.4 \pm 0.2$ & $7.4 \pm 0.1$ & $6.7 \pm 0.1$ & $20.8 \pm 0.3$ & $1.1 \pm 0.0$ & $0.017 \pm 0.001$ & $77.0 \pm 0.5$ \\
\hline 40 & $18 \pm 2$ & $25 \pm 2$ & $21 \pm 2$ & $902 \pm 81$ & $13.0 \pm 1.3$ & $13.9 \pm 0.2$ & $7.0 \pm 0.1$ & $6.1 \pm 0.1$ & $19.3 \pm 0.2$ & $1.1 \pm 0.0$ & $0.015 \pm 0.001$ & $75.0 \pm 0.2$ \\
\hline 41 & $22 \pm 2$ & $28 \pm 3$ & $24 \pm 2$ & $945 \pm 85$ & $2.7 \pm 0.3$ & $14.2 \pm 0.2$ & $6.2 \pm 0.0$ & $5.9 \pm 0.1$ & $17.7 \pm 0.4$ & $1.5 \pm 0.0$ & $0.003 \pm 0.001$ & $70.9 \pm 1.7$ \\
\hline 42 & $19 \pm 2$ & $27 \pm 2$ & $23 \pm 2$ & $959 \pm 86$ & $0.4 \pm 0.0$ & $13.9 \pm 0.2$ & $5.9 \pm 0.1$ & $6.0 \pm 0.1$ & $16.7 \pm 0.3$ & $1.3 \pm 0.0$ & $0.003 \pm 0.004$ & $68.0 \pm 0.4$ \\
\hline 43 & $23 \pm 2$ & $28 \pm 3$ & $24 \pm 2$ & $913 \pm 82$ & $1.9 \pm 0.2$ & $14.1 \pm 0.3$ & $5.8 \pm 0.1$ & $5.5 \pm 0.1$ & $17.0 \pm 0.2$ & $1.3 \pm 0.0$ & $0.001 \pm 0.002$ & $68.5 \pm 0.5$ \\
\hline 44 & $16 \pm 2$ & $25 \pm 2$ & $21 \pm 2$ & $970 \pm 87$ & $7.3 \pm 0.7$ & $11.7 \pm 0.1$ & $5.2 \pm 0.1$ & $5.1 \pm 0.1$ & $15.4 \pm 0.3$ & $1.1 \pm 0.0$ & $0.009 \pm 0.005$ & $66.2 \pm 0.9$ \\
\hline 45 & $34 \pm 3$ & $30 \pm 3$ & $26 \pm 3$ & $933 \pm 84$ & $1.7 \pm 0.2$ & $12.2 \pm 0.2$ & $5.3 \pm 0.1$ & $5.1 \pm 0.1$ & $17.1 \pm 0.7$ & $1.3 \pm 0.0$ & $0.005 \pm 0.003$ & $37.6 \pm 0.4$ \\
\hline 46 & $31 \pm 3$ & $27 \pm 2$ & $24 \pm 2$ & $911 \pm 82$ & $9.8 \pm 1.0$ & $13.0 \pm 0.3$ & $12.6 \pm 2.3$ & $6.1 \pm 0.1$ & $14.1 \pm 0.4$ & $0.9 \pm 0.0$ & $0.010 \pm 0.006$ & $97.7 \pm 2.9$ \\
\hline 47 & $31 \pm 3$ & $27 \pm 2$ & $24 \pm 2$ & $991 \pm 89$ & $0.6 \pm 0.1$ & $12.5 \pm 0.4$ & $7.7 \pm 0.2$ & $5.2 \pm 0.1$ & $12.8 \pm 0.5$ & $0.9 \pm 0.0$ & $0.006 \pm 0.003$ & $96.0 \pm 1.1$ \\
\hline 48 & $19 \pm 2$ & $28 \pm 3$ & $22 \pm 2$ & $991 \pm 89$ & $0.4 \pm 0.0$ & $10.7 \pm 0.3$ & $6.1 \pm 0.1$ & $4.4 \pm 0.1$ & $10.1 \pm 0.3$ & $0.8 \pm 0.0$ & $0.002 \pm 0.005$ & $97.4 \pm 1.6$ \\
\hline Mean $\pm \mathrm{SD}^{\mathrm{b}}$ & $26 \pm 6$ & $29 \pm 3$ & $25 \pm 3$ & $923 \pm 47$ & $5.6 \pm 0.6$ & $14.6 \pm 1.9$ & $5.4 \pm 0.1$ & $4.8 \pm 0.0$ & $18.1 \pm 2.6$ & $1.1 \pm 0.2$ & $0.009 \pm 0.006$ & $73.6 \pm 1.0$ \\
\hline MVC & $40 \pm 34$ & $49 \pm 3$ & $37 \pm 22$ & $580 \pm 202$ & - & 61 & 26.9 & 22.6 & 74.2 & 11.2 & 0.097 & 26 \\
\hline CSG I & & & & & & 90 & 40 & 35 & 100 & 15 & 0.2 & 35 \\
\hline CSG II & & & & & & 300 & 50 & 100 & 250 & 25 & 0.6 & 300 \\
\hline WAV & 35 & 45 & 32 & 412 & & & & & & & & \\
\hline
\end{tabular}

${ }^{a}$ Activity concentration \pm expanded uncertainty, ${ }^{\mathrm{b}}$ SD represents standard deviation; MVC: Mean values in China; CSG I: Chinese soil guidelines Grade I; CSG II: Chinese soil guidelines Grade II; WAV: world average values.

Table 3. The radiation hazard indices and lifetime cancer risk.

\begin{tabular}{ccccccc}
\hline & $\begin{array}{c}\text { Absorbed } \boldsymbol{\gamma} \text { Dose } \\
\text { Rate in Air }(\mathbf{n G y} / \mathbf{h})\end{array}$ & $\begin{array}{c}\text { Annual Effective } \\
\text { Dose }(\boldsymbol{\mu S v} / \mathbf{y})\end{array}$ & $\begin{array}{c}\text { Radium Equivalent } \\
\text { Activity (Bq/kg) }\end{array}$ & $\begin{array}{c}\text { External Hazard } \\
\text { Index }\end{array}$ & $\begin{array}{c}\text { Internal Hazard } \\
\text { Index }\end{array}$ & $\begin{array}{c}\text { Lifetime Cancer Risk } \\
\mathbf{( 1 / S v )}\end{array}$ \\
\hline Mean \pm SD & $76.7 \pm 3.1$ & $83.1 \pm 3.8$ & $138.0 \pm 6.8$ & $0.37 \pm 0.02$ & $0.44 \pm 0.03$ \\
Median & 67.9 & 83.3 & 138.78 & 0.37 & $3.2 \times 10^{-4} \pm 1.4 \times 10^{-5}$ \\
Min-max & $60.6-73.2$ & $74.3-83.3$ & $120.7-150.6$ & $0.33-0.41$ & $3.2 \times 10^{-4}$ & $0.37-0.49$ \\
\hline
\end{tabular}


Table 4. Daily doses, hazard quotients, hazard indices, and cancer risks of heavy metals for children.

\begin{tabular}{|c|c|c|c|c|c|c|c|c|c|}
\hline Heavy Metal & & $D_{\text {ing }}$ & $D_{\text {inh }}$ & $\mathrm{D}_{\text {dermal }}$ & $H_{Q_{\text {ing }}}$ & $H Q_{\text {inh }}$ & $\mathrm{HQ}_{\text {dermal }}$ & $\mathrm{HI}=\Sigma \mathrm{HQ}$ & Cancer Risk \\
\hline \multirow{3}{*}{$\mathrm{Cr}$} & Mean & $1.87 \times 10^{-4}$ & $5.22 \times 10^{-9}$ & $6.42 \times 10^{-6}$ & $6.23 \times 10^{-2}$ & $1.82 \times 10^{-4}$ & $1.07 \times 10^{-1}$ & $1.70 \times 10^{-1}$ & $2.33 \times 10^{-7}$ \\
\hline & Min & $1.37 \times 10^{-4}$ & $3.82 \times 10^{-9}$ & $4.70 \times 10^{-6}$ & $4.55 \times 10^{-2}$ & $1.33 \times 10^{-4}$ & $7.83 \times 10^{-2}$ & $1.24 \times 10^{-1}$ & $1.74 \times 10^{-7}$ \\
\hline & Max & $2.37 \times 10^{-4}$ & $6.61 \times 10^{-9}$ & $8.14 \times 10^{-6}$ & $7.89 \times 10^{-2}$ & $2.31 \times 10^{-4}$ & $1.36 \times 10^{-1}$ & $2.15 \times 10^{-1}$ & $3.06 \times 10^{-7}$ \\
\hline \multirow{3}{*}{$\mathrm{Ni}$} & Mean & $8.11 \times 10^{-5}$ & $2.27 \times 10^{-9}$ & $2.44 \times 10^{-5}$ & $4.05 \times 10^{-3}$ & $1.10 \times 10^{-7}$ & $4.52 \times 10^{-3}$ & $8.57 \times 10^{-3}$ & $2.11 \times 10^{-7}$ \\
\hline & Min & $5.83 \times 10^{-5}$ & $1.63 \times 10^{-9}$ & $1.76 \times 10^{-5}$ & $2.92 \times 10^{-3}$ & $7.91 \times 10^{-8}$ & $3.25 \times 10^{-3}$ & $6.17 \times 10^{-3}$ & $1.39 \times 10^{-7}$ \\
\hline & Max & $1.61 \times 10^{-4}$ & $4.50 \times 10^{-9}$ & $4.85 \times 10^{-5}$ & $8.06 \times 10^{-3}$ & $2.19 \times 10^{-7}$ & $8.99 \times 10^{-3}$ & $1.70 \times 10^{-2}$ & $3.80 \times 10^{-7}$ \\
\hline \multirow{2}{*}{$\mathrm{Cu}$} & Mean & $7.35 \times 10^{-5}$ & $2.05 \times 10^{-9}$ & $6.32 \times 10^{-6}$ & $1.84 \times 10^{-3}$ & $5.11 \times 10^{-8}$ & $5.27 \times 10^{-4}$ & $2.36 \times 10^{-3}$ & \\
\hline & Max & $1.15 \times 10^{-4}$ & $3.21 \times 10^{-9}$ & $9.89 \times 10^{-6}$ & $2.88 \times 10^{-3}$ & $7.99 \times 10^{-8}$ & $8.24 \times 10^{-4}$ & $3.70 \times 10^{-3}$ & \\
\hline \multirow{3}{*}{$\mathrm{Zn}$} & Mean & $2.31 \times 10^{-4}$ & $6.45 \times 10^{-9}$ & $3.97 \times 10^{-6}$ & $7.70 \times 10^{-4}$ & $2.15 \times 10^{-8}$ & $6.62 \times 10^{-5}$ & $8.36 \times 10^{-4}$ & \\
\hline & Min & $1.29 \times 10^{-4}$ & $3.62 \times 10^{-9}$ & $2.23 \times 10^{-6}$ & $4.32 \times 10^{-4}$ & $1.21 \times 10^{-8}$ & $3.71 \times 10^{-5}$ & $4.69 \times 10^{-4}$ & \\
\hline & Max & $3.23 \times 10^{-4}$ & $9.04 \times 10^{-9}$ & $5.56 \times 10^{-6}$ & $1.08 \times 10^{-3}$ & $3.01 \times 10^{-8}$ & $9.27 \times 10^{-5}$ & $1.17 \times 10^{-3}$ & \\
\hline \multirow{3}{*}{ As } & Mean & $1.46 \times 10^{-5}$ & $4.08 \times 10^{-10}$ & $3.77 \times 10^{-7}$ & $4.87 \times 10^{-2}$ & $1.36 \times 10^{-6}$ & $3.06 \times 10^{-3}$ & $5.17 \times 10^{-2}$ & $2.33 \times 10^{-5}$ \\
\hline & Min & $1.02 \times 10^{-5}$ & $2.85 \times 10^{-10}$ & $2.64 \times 10^{-7}$ & $3.41 \times 10^{-2}$ & $9.49 \times 10^{-7}$ & $2.14 \times 10^{-3}$ & $3.62 \times 10^{-2}$ & $1.63 \times 10^{-5}$ \\
\hline & Max & $1.98 \times 10^{-5}$ & $5.53 \times 10^{-10}$ & $5.11 \times 10^{-7}$ & $6.60 \times 10^{-2}$ & $1.84 \times 10^{-6}$ & $4.15 \times 10^{-3}$ & $7.01 \times 10^{-2}$ & $3.16 \times 10^{-5}$ \\
\hline \multirow{2}{*}{$\mathrm{Cd}$} & Mean & $1.15 \times 10^{-7}$ & $3.21 \times 10^{-12}$ & $1.38 \times 10^{-8}$ & $1.15 \times 10^{-4}$ & & $1.38 \times 10^{-3}$ & $1.50 \times 10^{-3}$ & $7.44 \times 10^{-11}$ \\
\hline & $\operatorname{Max}$ & $3.13 \times 10^{-7}$ & $8.76 \times 10^{-12}$ & $3.77 \times 10^{-8}$ & $3.13 \times 10^{-4}$ & & $3.77 \times 10^{-3}$ & $4.09 \times 10^{-3}$ & $2.02 \times 10^{-10}$ \\
\hline \multirow{3}{*}{$\mathrm{Pb}$} & Mean & $9.41 \times 10^{-4}$ & $2.63 \times 10^{-8}$ & $4.86 \times 10^{-6}$ & $2.69 \times 10^{-1}$ & $7.47 \times 10^{-6}$ & $9.25 \times 10^{-3}$ & $2.78 \times 10^{-1}$ & \\
\hline & Min & $4.80 \times 10^{-4}$ & $1.34 \times 10^{-8}$ & $2.48 \times 10^{-6}$ & $1.37 \times 10^{-1}$ & $3.81 \times 10^{-6}$ & $4.72 \times 10^{-3}$ & $1.42 \times 10^{-1}$ & \\
\hline & $\operatorname{Max}$ & $1.25 \times 10^{-3}$ & $3.49 \times 10^{-8}$ & $6.45 \times 10^{-6}$ & $3.57 \times 10^{-1}$ & $9.92 \times 10^{-6}$ & $1.23 \times 10^{-2}$ & $3.69 \times 10^{-1}$ & \\
\hline
\end{tabular}


Table 5. Daily doses, hazard quotients, hazard indices, and cancer risks of heavy metals for adults.

\begin{tabular}{|c|c|c|c|c|c|c|c|c|c|}
\hline Heavy Metal & & $\mathrm{D}_{\text {ing }}$ & $\mathrm{D}_{\text {inh }}$ & $\mathrm{D}_{\text {dermal }}$ & $\mathrm{HQ}_{\text {ing }}$ & $\mathrm{HQ}_{\mathrm{inh}}$ & $\mathrm{HQ}_{\text {dermal }}$ & $\mathrm{HI}=\Sigma \mathrm{HQ}$ & Cancer Risk \\
\hline \multirow{3}{*}{$\mathrm{Cr}$} & Mean & $2.00 \times 10^{-5}$ & $2.94 \times 10^{-9}$ & $8.57 \times 10^{-7}$ & $6.67 \times 10^{-3}$ & $1.03 \times 10^{-4}$ & $1.43 \times 10^{-2}$ & $2.11 \times 10^{-2}$ & $1.24 \times 10^{-7}$ \\
\hline & Min & $1.46 \times 10^{-5}$ & $2.15 \times 10^{-9}$ & $6.27 \times 10^{-7}$ & $4.88 \times 10^{-3}$ & $7.52 \times 10^{-5}$ & $1.04 \times 10^{-2}$ & $1.54 \times 10^{-2}$ & $9.04 \times 10^{-8}$ \\
\hline & Max & $2.54 \times 10^{-5}$ & $3.73 \times 10^{-9}$ & $1.09 \times 10^{-6}$ & $8.45 \times 10^{-3}$ & $1.30 \times 10^{-4}$ & $1.81 \times 10^{-2}$ & $2.67 \times 10^{-2}$ & $1.57 \times 10^{-7}$ \\
\hline \multirow{3}{*}{$\mathrm{Ni}$} & Mean & $8.69 \times 10^{-6}$ & $1.28 \times 10^{-9}$ & $3.26 \times 10^{-6}$ & $4.34 \times 10^{-4}$ & $6.20 \times 10^{-8}$ & $6.03 \times 10^{-4}$ & $1.04 \times 10^{-3}$ & $1.07 \times 10^{-7}$ \\
\hline & Min & $6.25 \times 10^{-6}$ & $9.19 \times 10^{-10}$ & $2.34 \times 10^{-6}$ & $3.12 \times 10^{-4}$ & $4.46 \times 10^{-8}$ & $4.34 \times 10^{-4}$ & $7.46 \times 10^{-4}$ & $7.72 \times 10^{-8}$ \\
\hline & Max & $1.73 \times 10^{-5}$ & $2.54 \times 10^{-9}$ & $6.48 \times 10^{-6}$ & $8.64 \times 10^{-4}$ & $1.23 \times 10^{-7}$ & $1.20 \times 10^{-3}$ & $2.06 \times 10^{-3}$ & $2.13 \times 10^{-7}$ \\
\hline \multirow{2}{*}{$\mathrm{Cu}$} & Mean & $7.87 \times 10^{-6}$ & $1.16 \times 10^{-9}$ & $8.43 \times 10^{-7}$ & $1.97 \times 10^{-4}$ & $2.88 \times 10^{-8}$ & $7.03 \times 10^{-5}$ & $2.67 \times 10^{-4}$ & \\
\hline & Max & $1.23 \times 10^{-5}$ & $1.81 \times 10^{-9}$ & $1.32 \times 10^{-6}$ & $3.08 \times 10^{-4}$ & $4.51 \times 10^{-8}$ & $1.10 \times 10^{-4}$ & $4.18 \times 10^{-4}$ & \\
\hline \multirow{3}{*}{$\mathrm{Zn}$} & Mean & $2.47 \times 10^{-5}$ & $3.64 \times 10^{-9}$ & $5.30 \times 10^{-7}$ & $8.25 \times 10^{-5}$ & $1.21 \times 10^{-8}$ & $8.83 \times 10^{-6}$ & $9.13 \times 10^{-5}$ & \\
\hline & Min & $1.39 \times 10^{-5}$ & $2.04 \times 10^{-9}$ & $2.97 \times 10^{-7}$ & $4.62 \times 10^{-5}$ & $6.80 \times 10^{-9}$ & $4.95 \times 10^{-6}$ & $5.12 \times 10^{-5}$ & \\
\hline & $\operatorname{Max}$ & $3.47 \times 10^{-5}$ & $5.10 \times 10^{-9}$ & $7.42 \times 10^{-7}$ & $1.16 \times 10^{-4}$ & $1.70 \times 10^{-8}$ & $1.24 \times 10^{-5}$ & $1.28 \times 10^{-4}$ & \\
\hline \multirow{3}{*}{ As } & Mean & $1.56 \times 10^{-6}$ & $2.30 \times 10^{-10}$ & $5.03 \times 10^{-8}$ & $5.21 \times 10^{-3}$ & $7.64 \times 10^{-7}$ & $4.09 \times 10^{-4}$ & $5.62 \times 10^{-3}$ & $2.53 \times 10^{-6}$ \\
\hline & Min & $1.09 \times 10^{-6}$ & $1.61 \times 10^{-10}$ & $3.52 \times 10^{-8}$ & $3.65 \times 10^{-3}$ & $5.35 \times 10^{-7}$ & $2.86 \times 10^{-4}$ & $3.94 \times 10^{-3}$ & $1.77 \times 10^{-6}$ \\
\hline & $\operatorname{Max}$ & $2.12 \times 10^{-6}$ & $3.12 \times 10^{-10}$ & $6.81 \times 10^{-8}$ & $7.07 \times 10^{-3}$ & $1.04 \times 10^{-6}$ & $5.54 \times 10^{-4}$ & $7.62 \times 10^{-3}$ & $3.44 \times 10^{-6}$ \\
\hline $\mathrm{Cd}$ & Max & $3.36 \times 10^{-8}$ & $4.94 \times 10^{-12}$ & $5.04 \times 10^{-9}$ & $3.36 \times 10^{-5}$ & & $5.04 \times 10^{-4}$ & $5.37 \times 10^{-4}$ & $3.11 \times 10^{-11}$ \\
\hline \multirow{3}{*}{$\mathrm{Pb}$} & Mean & $1.01 \times 10^{-4}$ & $1.48 \times 10^{-8}$ & $6.48 \times 10^{-7}$ & $2.88 \times 10^{-2}$ & $4.21 \times 10^{-6}$ & $1.23 \times 10^{-3}$ & $3.01 \times 10^{-2}$ & \\
\hline & Min & $5.14 \times 10^{-5}$ & $7.56 \times 10^{-9}$ & $3.31 \times 10^{-7}$ & $1.47 \times 10^{-2}$ & $2.15 \times 10^{-6}$ & $6.30 \times 10^{-4}$ & $1.53 \times 10^{-2}$ & \\
\hline & $\operatorname{Max}$ & $1.34 \times 10^{-4}$ & $1.97 \times 10^{-8}$ & $8.60 \times 10^{-7}$ & $3.82 \times 10^{-2}$ & $5.59 \times 10^{-6}$ & $1.64 \times 10^{-3}$ & $3.99 \times 10^{-2}$ & \\
\hline
\end{tabular}




\subsection{Correlation Analysis}

The correlations between the natural radionuclides and the heavy metals in the surface soil samples were performed using the SPSS computer package, Version 19 for Windows. The statistical significance of the Pearson correlation was determined by the $t$ test $[30,31]$. If a value was close to zero, there was no association between the two elements. The terms "weak", "moderate", and "strong" were presented for correlation coefficients of $0.2-0.4,0.4-0.6$, and $>0.6$, respectively [31]. The alpha level for testing significance was set at 0.01 and 0.05 . The Pearson correlations of the heavy metals and radionuclides are shown in Table 6 . It was found that ${ }^{238} \mathrm{U}$ was weakly positively correlated with ${ }^{232} \mathrm{Th}$ and ${ }^{226} \mathrm{Ra}$ at the 0.05 significance level. A strong positive correlation between ${ }^{232} \mathrm{Th}$ and ${ }^{226} \mathrm{Ra}$ at the 0.01 significance level was present. Both the radionuclides ${ }^{232} \mathrm{Th}$ and ${ }^{226} \mathrm{Ra}$ moderately positively correlated with $\mathrm{Cr}$ and $\mathrm{Zn}$, and weakly correlated with ${ }^{40} \mathrm{~K}$ and Ni. There were also strong positive correlations between heavy metals: $\mathrm{Cr}$ and $\mathrm{Zn}, \mathrm{Ni}$ and $\mathrm{Cu}$, and $\mathrm{Cu}$ and $\mathrm{Zn}$. These strong correlations among metals and radionuclides suggest their common origin. However, there are observed moderate or strong negative correlations between the radionuclide ${ }^{40} \mathrm{~K}$ with $\mathrm{Ni}, \mathrm{Cu}$, and $\mathrm{Zn}$ at the 0.01 significance level. Additionally, it was found that no correlations exist between the radionuclides and heavy metals, i.e., $\mathrm{Cr}$ and ${ }^{40} \mathrm{~K}$. The absence of correlations could be explained by the mutual independence or different behavior of the elements.

Table 6. The pearson correlation matrix for the natural radionuclides and the heavy metals.

\begin{tabular}{|c|c|c|c|c|c|c|c|c|c|c|c|}
\hline & ${ }^{238} \mathrm{U}$ & ${ }^{232} \mathrm{Th}$ & ${ }^{226} \mathrm{Ra}$ & ${ }^{40} \mathrm{~K}$ & $\mathrm{Cr}$ & $\mathbf{N i}$ & $\mathrm{Cu}$ & $\mathrm{Zn}$ & As & $\mathrm{Cd}$ & $\mathrm{Pb}$ \\
\hline${ }^{238} \mathrm{U}$ & 1 & $0.344^{a}$ & $0.333^{\mathrm{a}}$ & 0.032 & -0.002 & 0.192 & 0.224 & 0.261 & 0.173 & 0.146 & 0.045 \\
\hline${ }^{232} \mathrm{Th}$ & & 1 & $0.933^{b}$ & $-0.367^{a}$ & $0.421^{b}$ & $0.298^{\mathrm{a}}$ & $0.497^{b}$ & $0.512^{b}$ & 0.233 & -0.035 & 0.0 .35 \\
\hline${ }^{226} \mathrm{Ra}$ & & & 1 & $-0.303^{a}$ & $0.407^{b}$ & $0.297^{\mathrm{a}}$ & $0.399^{\mathrm{b}}$ & $0.446^{\mathrm{b}}$ & 0.144 & -0.111 & 0.040 \\
\hline${ }^{40} \mathrm{~K}$ & & & & 1 & -0.009 & $-0.439^{b}$ & $-0.590^{b}$ & $-0.483^{b}$ & -0.239 & $-0.619^{b}$ & 0.127 \\
\hline $\mathrm{Cr}$ & & & & & 1 & 0.098 & 0.264 & $0.622^{b}$ & 0.13 & 0.082 & 0.219 \\
\hline $\mathrm{Ni}$ & & & & & & 1 & $0.756^{\mathrm{b}}$ & $0.333^{\mathrm{a}}$ & 0.179 & $0.414^{\mathrm{b}}$ & $0.375^{\mathrm{b}}$ \\
\hline $\mathrm{Cu}$ & & & & & & & 1 & $0.737^{\mathrm{b}}$ & $0.547^{\mathrm{b}}$ & $0.544^{\mathrm{b}}$ & 0.090 \\
\hline $\mathrm{Zn}$ & & & & & & & & 1 & $0.497^{b}$ & $0.538^{b}$ & -0.032 \\
\hline As & & & & & & & & & 1 & 0.168 & $-0.386^{b}$ \\
\hline $\mathrm{Cd}$ & & & & & & & & & & 1 & 0.092 \\
\hline $\mathrm{Pb}$ & & & & & & & & & & & 1 \\
\hline
\end{tabular}

${ }^{\mathrm{a}}$ Correlation is significant at the 0.05 level; ${ }^{\mathrm{b}}$ Correlation is significant at the 0.01 level.

\section{Conclusions}

The radionuclides $\left({ }^{238} \mathrm{U},{ }^{232} \mathrm{Th},{ }^{226} \mathrm{Ra},{ }^{40} \mathrm{~K},{ }^{137} \mathrm{Cs}\right)$ and heavy metals were measured in 48 surface soil samples from the Bayanwula prospective uranium mining area in China. Activity concentrations of ${ }^{238} \mathrm{U},{ }^{232} \mathrm{Th}$, and ${ }^{226} \mathrm{Ra}$ were lower than the world average except for ${ }^{40} \mathrm{~K}$. The values obtained were within the acceptable limits. The annual effective dose and various radiation hazard indices indicate that there is low radiological risk to the local populations around the uranium mining area. The contents of the heavy metals $\mathrm{Cr}, \mathrm{Ni}, \mathrm{Cu}, \mathrm{Zn}, \mathrm{As}$, and $\mathrm{Cd}$ were within the Chinese soil guidelines Grade I except for $\mathrm{Pb}$, which was about three times higher than the average of China. The non-cancer risk index and cancer risk were estimated to be less than the acceptable limits. The risks of heavy metals for children are all higher than that for adults. A strong positive correlation between radionuclides and heavy metals at the 0.01 significance level was found which suggests their common origin. The correlation study also indicated negative and weak correlations between the radionuclides and heavy metals. This study established the baseline information regarding the natural, artificial radioactivity, and heavy metals status around the Bayanwula prospective uranium mining area in China. To the best of our knowledge, this is the first systematic and large scale study on radiation levels around prospective uranium mining areas in China. These background data could be an important reference for public environmental concerns. 
Acknowledgments: The authors would like to thank Guilin Bai from the XilinGol center for disease control and prevention, and Huhejiletu from the Sonid Left center for disease control and prevention for their help with the sampling work.

Author Contributions: Haribala Bai, Bitao Hu, and Yuhong Li wrote the article; Haribala Bai, Chengguo Wang, Gerilemandahu Sai, Xiao Xu, and Shuai Zhang performed the sampling work, conducted the experiments, and processed the data; Shanhu Bao mapped Figure 1.

Conflicts of Interest: The authors declare no conflict of interest.

\section{References}

1. Carvalho, F.P.; Madruga, M.J.; Reis, M.C.; Alves, J.G.; Oliveira, J.M.; Gouveia, J.; Silva, L. Radioactivity in the environment around past radium and uranium mining sites of Portugal. J. Environ. Radioact. 2007, 96, $39-46$. [CrossRef] [PubMed]

2. Neiva, A.M.R.; Antunes, I.M.H.R.; Carvalho, P.C.S.; Santos, A.C.T. Uranium and arsenic contamination in the former Mondego Sul uranium mine area, Central Portugal. J. Geochem. Explor. 2016, 162, 1-15. [CrossRef]

3. Foulkes, M.; Millward, G.; Henderson, S.; Blake, W. Bioaccessibility of U, Th and Pb in solid wastes and soils from an abandoned uranium mine. J. Environ. Radioact. 2016. [CrossRef] [PubMed]

4. Corcho Alvarado, J.A.; Balsiger, B.; Röllin, S.; Jakob, A.; Burger, M. Radioactive and chemical contamination of the water resources in the former uranium mining and milling sites of Mailuu Suu (Kyrgyzstan). J. Environ. Radioact. 2014, 138, 1-10. [CrossRef] [PubMed]

5. International Atomic Energy Agency. Environmental Contamination from Uranium Production Facilities and Their Remediation. Available online: http://www-pub.iaea.org/MTCD/publications/PDF/Pub1228_ web.pdf (accessed on 3 September 2014).

6. United Nations Scientifc Committee on the Effects of Atomic Radiation. Sources and Effects of Ionizing Radiation. Available online: http://www.unscear.org/docs/reports/2008/09--86753_Report_2008_Annex_ B.pdf (accessed on 6 Spetember 2008).

7. Pan, Z. The dose contribution from technologically enhanced naturally occurring radioactive materials should be paid attention. Chin. J. Radiol. Med. Prot. 2014, 34, 321-322.

8. International Atomic Energy Agency. Radiation Protection and Safety of Radiation Sources: International Basic Safety Standards. Available online: http:/ /www-pub.iaea.org/MTCD/publications/PDF/Pub1578_ web-57265295.pdf (accessed on 9 September 2014)

9. United Nations. Report of the United Nations Scientific Committee on the Effects of Atomic. Available online: https://books.google.com.vn/books?hl=vi\&lr=\&id=lN5o37NwtwMC\&oi=fnd\&pg=PA1\&dq= Report+of+the+United+Nations+Scientific + Committee+on+the+Effects + of + Atomic + Radiation+to+the+ General+Assemby.Annex+B+Exposures+from+natural+radiation+sources\&ots=0rXqVRsgNM\&sig=cyi6w7318E3jC_Yz8hDq3lldU0\&redir_esc=y\#v=onepage\&q\&f=false (accessed on 5 September 2000).

10. Korkulu, Z.; Özkan, N. Determination of natural radioactivity levels of beach sand samples in the black sea coast of Kocaeli (Turkey). Radiat. Phys. Chem. 2013, 88, 27-31. [CrossRef]

11. Luevano-Gurrola, S.; Perez-Tapia, A.; Pinedo-Alvarez, C.; Carrillo-Flores, J.; Montero-Cabrera, M.E.; Renteria-Villalobos, M. Lifetime effective dose assessment based on background outdoor gamma exposure in Chihuahua City, Mexico. Int. J. Environ. Res. Public Health 2015, 12, 12324-12339. [CrossRef] [PubMed]

12. The 2007 Recommendations of the International Commission on Rasiological Protection. Available online: https:/ / edisciplinas.usp.br/pluginfile.php/235351/mod_resource/content/1/ICRP_103_todo.pdf (accessed on 2 May 2007).

13. Pan, Z. Radiation Safety Manual. (In Chinese). Available online: http://www.linguee.com/english-chinese/ translation/radiation+safety+manual.html (accessed on 6 September 2004).

14. Bai, H.; Hu, B.; Wang, C.; Sai, G.; Xu, X.; Zhang, S.; Bao, S.; Li, Y. Assessment of radioactive materials and heavy metals in the surface soil around uranium mining area of Tongliao, China. Ecotoxicol. Environ. Saf. 2016, 130, 185-192. 
15. Miao, X.; Ji, Y.; Shao, X.; Wang, H.; Sun, Q.; Su, X. Radioactivity of drinking-water in the vicinity of nuclear power plants in China based on a large-scale monitoring study. Int. J. Environ. Res. Public Health 2013, 10, 6863-6872. [CrossRef] [PubMed]

16. Wang, J.; Li, H.; Liu, J.; Chen, Y.; Song, G.; Chen, D.; Wang, C. Progress on radioactive pollution and related problems caused by uranium mining. J. Environ. Health 2013, 30, 1033-10036.

17. Karunakara, N.; Yashodhara, I.; Sudeep Kumara, K.; Tripathi, R.M.; Menon, S.N.; Kadam, S.; Chougaonkar, M.P. Assessment of ambient gamma dose rate around a prospective uranium mining area of South India-A comparative study of dose by direct methods and soil radioactivity measurements. Results Phys. 2014, 4, 20-27. [CrossRef]

18. Veiga, R.; Sanches, N.; Anjos, P.M.; Macario, K.; Bastos, J.; Iguatemy, M.; Aguiar, J.G.; Santos, A.M.A.; Mosquera, B.; Carvalho, C.; et al. Measurement of natural radioactivity in Brazilian beach sands. Radiat. Meas. 2006, 41, 189-196. [CrossRef]

19. Hamideen, M.S.; Sharaf, J. Natural radioactivity investigations in soil samples obtained from phosphate hills in the Russaifa region, Jordan. Radiat. Phys. Chem. 2012, 81, 1559-1562. [CrossRef]

20. Ferreira-Baptista, L.; De Miguel, E. Geochemistry and risk assessment of street dust in Luanda, Angola: A tropical urban environment. Atmos. Environ. 2005, 39, 4501-4512. [CrossRef]

21. Lu, X.; Zhang, X.; Li, L.Y.; Chen, H. Assessment of metals pollution and health risk in dust from nursery schools in Xi'an, China. Environ. Res. 2014, 128, 27-34. [CrossRef] [PubMed]

22. United States Environmental Protection Agency. Cancer Risk Coefficients for Environmental Exposure to Radionuclides. Available online: https://nepis.epa.gov/Exe/ZyNET.exe/00000C9E. TXT?ZyActionD=ZyDocument\&Client=EPA\&Index=1995+Thru+1999\&Docs=\&Query=\&Time= $\&$ EndTime $=\&$ SearchMethod $=1 \&$ TocRestrict $=$ n $\&$ Toc $=\&$ TocEntry $=\& Q$ Field $=\& Q$ Field Year $=\& Q$ FieldMonth $=$ $\& Q F i e l d D a y=\& I n t Q F i e l d O p=0 \& E x t Q F i e l d O p=0 \& X m l Q u e r y=\& F i l e=D \% 3 A \backslash z y$ files $\backslash$ Index $\% 20$ Data $\backslash$ 95thru99 \Txt $\backslash 00000013 \backslash 00000 C 9 E$.txt\&User=ANONYMOUS\&Password=anonymous\&SortMethod= $\mathrm{h} \backslash \mathrm{T} 1 \backslash$ textbar $\{$-\&MaximumDocuments=1\&FuzzyDegree=0\&ImageQuality=r75g8/r75g8/x150y150g16/ i425\&Display=hpfr\&DefSeekPage $=x \& S e a r c h B a c k=Z y$ ActionL\&Back=ZyActionS\&BackDesc $=$ Results $\%$ 20page \&MaximumPages $=1 \& Z y$ Entry $=1 \&$ SeekPage $=x \& Z y P U R L$ (accessed on 8 June 1999).

23. United States Environmental Protection Agency. Supplemental Guidance for Developing Soil Screening Levels for Superfund Sites. Available online: https://nepis.epa.gov/Exe/ZyNET.exe/ 91003IJK.TXT?ZyActionD=ZyDocument\&Client=EPA\&Index=2000+Thru+2005\&Docs=\&Query=\&Time= \&EndTime $=\&$ SearchMethod $=1 \&$ TocRestrict $=$ n\&Toc $=\&$ TocEntry $=\& Q$ Field $=\& Q$ FieldYear $=\& Q$ FieldMonth $=$ $\& Q F i e l d D a y=\& I n t Q F i e l d O p=0 \& E x t Q F i e l d O p=0 \& X m l Q u e r y=\& F i l e=D \% 3 A \backslash z y$ files $\backslash$ Index $\% 20$ Data $\backslash$ 00thru05 $\backslash$ Txt $\backslash 00000023 \backslash 91003 I J K . t x t \& U s e r=A N O N Y M O U S \& P a s s w o r d=$ anonymous\&SortMethod=h $\backslash$ T1 \textbar\{\}-\&MaximumDocuments=1\&FuzzyDegree=0\&ImageQuality=r75g8/r75g8/x150y150g16/ i425\&Display $=$ hpfr\&DefSeekPage $=x \&$ SearchBack $=$ ZyActionL\&Back $=$ ZyActionS\&BackDesc $=$ Results $\%$ 20page \&MaximumPages $=1 \& Z y$ Entry $=1 \&$ SeekPage $=x \& Z y P U R L$ (accessed on 7 September 2002).

24. Xu, S.; Zheng, N.; Liu, J.; Wang, Y.; Chang, S. Health risk assessment of arsenic exposure to street dust in the zinc smelting district, Northeast China. Environ. Geochem. Health 2013, 35, 89-99. [CrossRef] [PubMed]

25. Cheng, H.; Teng, Y.; Lu, S.; Wang, Y.; Wang, J. Contamination features and health risk of soil heavy metals in China. Sci. Total Environ. 2015, 512-513, 143-153. [CrossRef] [PubMed]

26. The Summary Report Group for National Environmental Survey. The investigation on nationwide gamma radiation (1983-1990). Radiat. Prot. 1992, 12, 97-121.

27. Chen, H.; Lu, X.; Li, L.Y. Spatial distribution and risk assessment of metals in dust based on samples from nursery and primary schools of Xi'an, China. Atmos. Environ. 2014, 88, 172-182. [CrossRef]

28. China National Environmental Monitoring Center. The Background Values of Elements in Chinese Soils. Available online: http://www.hjkx.ac.cn/hjkx/ch/reader/create_pdf.aspx?file_no=19910406 (accessed on 6 September 1991).

29. Chinese Standard. GB 15618-1995 Soil Environmental Quality Standards; Standard Press of China: Beijing, China, 1995. 
30. Gulan, L.; Milenkovic, B.; Stajic, J.M.; Vuckovic, B.; Krstic, D.; Zeremski, T.; Ninkov, J. Correlation between radioactivity levels and heavy metal content in the soils of the North Kosovska Mitrovica environment. Environ. Sci. Process. Impacts 2013, 15, 1735-1742. [CrossRef]

31. Gulan, L.; Milenkovic, B.; Zeremski, T.; Milic, G. Persistent organic pollutants, heavy metals and radioactivity in the urban soil of Pri stina City, Kosovo and Metohija. Chemosphere 2017, 171, 415-426. [CrossRef] [PubMed]

(c) 2017 by the authors. Licensee MDPI, Basel, Switzerland. This article is an open access article distributed under the terms and conditions of the Creative Commons Attribution (CC BY) license (http:/ / creativecommons.org/licenses/by/4.0/). 